\title{
OR $\mathbf{X}$
}

Vol. XIV No. 2

December 1977

\section{Notes and News}

The Geneva working meeting last October of the CITES (Convention on International Trade in Endangered Species) left feelings of dissatisfaction in many of those present. On the surface it had achieved all, and perhaps more than all, it had set out to do: to tidy up the Convention,

Two Cheers and make proposals for the next full meeting of the for Parties, now numbering 41, scheduled for Costa Rica in CITES February 1979. A suggestion put forward on the last day, and widely supported was that, since exporting nations often lacked the expertise to restrict trade, the importing nations should impose their own regulations, even for abundant species. In effect this means that the UK, USA and other developed nations should set import quotas for tortoises, reptile skins and other bulk imports until such time as enough is known about the species for the producer nations to control the species. This was valuable. But behind all the hard work those present put into the tidying up process, there was a slowly dawning horror among the administrators as to what their governments had let them in for. At Washington in 1973, when CITES was originally set up and signed, few administrators realised that more than a handful of endangered species were involved: the whooping crane, of course, great apes, tigers, perhaps the leopard and cheetah, and a few more. But as country after country arrived with its shopping list of obscure animals - and even worse, plants - demanding that they be included, disillusion set in. Now as the global situation worsens, and animal after animal reaches the threshold of endangerment, it is becoming clear that the British solution of 'reverse listing', i.e. prohibiting everything except a small free list of common species, is the only satisfactory one in the long run, and some other 
countries are introducing similar systems. This will not be accepted in Costa Rica, but at the meeting after that, either reverse listing will be agreed, or the Convention will collapse as unenforceable.

Two major conservation prizes have been awarded to prominent conservationists closely connected with FPS, both richly deserved. Our Chairman Sir Peter Scott shared with Jacques Cousteau the $\$ 50,000$ Pahlavi Environment Prize, awarded by the Government of Iran, for his Two outstanding contribution in the field of the environment, Conservation and our Vice-President Major Ian Grimwood received Prizes the 1977 Getty Prize awarded for outstanding achievements in the conservation of wildlife. Ian Grimwood has been connected with wildlife conservation and a staunch friend of FPS ever since the days of Operation Noah - the rescue of wild animals from the Kariba lake as it filled behind the new dam - and the 1962 Operation Oryx, which he led on behalf of FPS, to capture Arabian oryx with which to start the captive breeding herd that now numbers nearly 100 animals. He was in turn on the staff of the Northern Rhodesian (now Zambian) Game Department and Chief Game Warden of Kenya for five years from 1959, since when he has been a roving conservation consultant for FAO, IUCN and other organisations, advising governments in several continents on their svildlife - in Ethiopia, the Galapagos Islands, Peru, Colombia, Pakistan, Swaziland, Botswana, and many countries in South-East Asia and West Africa - and has written regularly for Oryx. He is now in Latin America again on a tour for IUCN of the southern countries of that continent.

The lethal combination of high fashion and East African poaching has brought disaster to Grevy's zebra Equus grevyi, whose numbers in northern Kenya have crashed from 10,000 to a possible 1000 , since 1971 , and there are reports of skins selling at up to $\$ 2000$ apiece. A well-qualiCrash of fied observer in Kenya said in the summer that by the end a of 1977 'there will be more Grevy's zebra in captivity than Zebra in their natural range'. The decline has been so sudden that conservationists have been caught off-balance: Grevy's zebra is listed only as 'vulnerable' in the IUCN Red Data Book and is unlisted in the international trade convention. An emergency translocation programme has been mounted by William Holden and Don Hunt of the Mount Kenya Game Ranch, partially backed by the Kenya Government, to take a breeding stock from the unprotected north to Samburu and Tsavo National Parks, and FPS and WWF are co-sponsoring Operation Zebra to raise funds for similar rescue operations, keep a studbook of the Grevy's zebras in captivity outside Africa and, equally important, watch what happens to Burchell's zebra $E$. burchelli before a decline there also becomes catastrophic. There are no population figures for Burchell's; it is reckoned to be numerous and widespread, but so are the hunters, or rather poachers, for Kenya has banned all hunting. This, too, is a two-edged weapon. Will not the 

preserving one-square-mile (259-ha) blocks in each reserve forest as wildlife sanctuaries, chosen at random. A survey to find the best areas for the wood ducks could ensure that their preservation was a primary consideration. Moreover, fewer but larger sanctuaries ( 1000 ha each) would be much more effective without sterilising any greater area of forest.

The outlook for primates in Bangladesh is gloomy, is the burden of a report by Ken Green, of the Smithsonian Institution, following his six-month study in 1976. All primates there, except rhesus monkeys (now a serious agricultural pest), require forest to survive, and Bangladesh is destroyMonkeys
Disappear with
the Forests ing forest at what can only be an accelerating rate, given the very dense and rapidly increasing human population for whom wood is both the main fuel and main housebuilding material. Moreover, the conversion of mixed forest into sal plantation, the promotion of teak-growing and the spread of tea gardens produce monocultures that are poor or useless habitat for monkeys. Primates are wanted for biomedical research, but Ken Green urges that cropping for this purpose should be stopped if the research does not include long-term studies of the effects on the monkey populations. The survey did not cover the Chittagong Hill Tracts nor the Sunderbans; nevertheless a combination of the survey results and published reports produced what he calls a surprisingly low primate abundance in Bangladesh. His rough estimate of the total population was 125,000. Local people, when questioned, confirmed the decrease in monkeys: at one time they said monkeys were there, but now they had 'left'. Seven species are found in Bangladesh: Mycticebus coucang, Macaca mulatta, nemestrina and assamensis, Presbytis pileatus and phayrei and Hylobates hoolock.

A whole range of Australia's native fauna and flora, including species not yet scientifically described, is threatened by extensive clear-cutting of sub-tropical rain forest in the Conondale Range, in Queensland, and replanting with softwoods, mainly exotic pine. Moreover, because the

Unjustified Forest Sacrifice topography of the range dictates that much of the clear-cutting is on hillsides, the soil erodes while the pines are still too small to hold it, causing siltage and flooding in streams running through otherwise untouched parts of the forest. Among the many species native - and in some cases endemic - to the forest are platypus, spiny anteater, various bandicoots and wallabies, plumed frogmouth, powerful and sooty owl. A Government offer of a 1700-ha national park in the Range (the existing one is only $300 \mathrm{ha}$ ) has been termed 'totally inadequate' by the Queensland Conservation Council. Pine plantations are the most serious actual and potential encroachment, but there are also gold mines, a growing woodchip industry and the 'die-back' root fungus Phytopthora cinnamoni, which has already destroyed large sections of forest elsewhere in Australia and is believed to be spread by road-making and machinery. A 1974 study of the pine plantations suggested that the 1.5 million 
ha of softwoods estimated as necessary for Australia's domestic needs in 2000 AD was based on outdated population estimates and that a truer figure would be 680,000 ha, less than half.

The Haitian hutia Plagiodontia aedium and the Haitian solenodon Solenodon paradoxus are both close to extinction in the wild. Small hutia populations survive, but they are mainly in unfavourable habitats where human population is increasing; with a breeding rate of only one young a

Endangered Species in Haiti year the species is unlikely to survive another decade. Of the solenodon probably fewer than 100 individuals survive, and 'there is no hope of saving the species without the assistance of protected habitats in a national park' - and even then it would require desperate efforts to create the right conditions for a breeding population. These are the conclusions of two scientists Dr Charles A. Woods and Dr Richard C. Rosen, of the University of Vermont, who have spent 26 weeks in the field and worked on the two species since 1973. Loss of forest - i.e. habitat destruction - is the main cause of both species' decline. They recommend areas for two reserves or national parks, both in remote parts of the less populous southern peninsula, which could save not only the hutia and the solenodon, but also other animals and birds, and some of the native forest which is almost gone.

In 1976 Richard J. Moore, aided by an Oryx 100\% Fund grant, made a survey of turtles nesting in the Suakin Archipelago, a cluster of coral islands between 15 and 50 miles off the coast between Port Sudan and the Ethiopian border. Turtles have long been known to nest there, but had never

Red Sea

Turtle Surveys been studied or counted. He found evidence of about 1000 female hawksbills Eretmochelys imbricata nesting in the islands, fewer than might be expected in such a remote and reasonably unpolluted area with few land-based predators, but he found mounds of shells and bones interspersed with such relics as a 19th-century gin bottle, suggesting that the turtle population has still to recover from the depredations of hungry sailors in the early days of the Suez Canal. Encouraged by Moore's work, the Arab League Educational, Cultural and Scientific Organisation has agreed to finance a turtle survey on the rest of the Red Sea and Gulf of Aden coasts and to follow this with a training programme for scientists to staff a permanent conservation programme.

Tourists in the Serengeti may be inadvertently endangering some animals they have come to admire, because some predators and scavengers have learned to use parked minibuses as guides to fresh kills. Cheetahs are particularly vulnerable for not only are they popular with tourists, Tourist but, being solitary, the mother has to leave her cubs Hazard for unprotected while she hunts, and spends so much energy Cheetahs in catching her small fast prey, usually gazelles, that she is too exhausted to fight. In normal circumstances cheetahs lose much of their kills and 70 per cent of their cubs to predators-lions, 
leopards, hyenas and birds of prey - which leaves too narrow a margin to allow for a tourist hazard. And in the Serengeti there is still virtually no control over tourist movement.

The granting of outline planning permission for a mink farm in one of the main Orkney islands, Westray, in May this year, brought widespread protests, quite predictably. The American mink Mustela vison is a killer and omnivorous - it eats almost anything, can live almost Does anywhere, has few natural predators, and can swim. Such Orkney Want is the damage that escaped animals can do - and have Mink? done in many parts of Europe, e.g. in decimating the waterfowl on Iceland's major lake, Myvatn and almost exterminating that of Lake Thingvalla - that until 1970 the UK Ministry of Agriculture made a serious effort to exterminate this pest, but after eight years, with 6500 caught, had to give up. The first mink farm started in Britain in the 1920s; by 1967 there were about 700 . Since then, because only large farms are viable, the numbers of farms have declined but pelt production has increased, from 6000 in 1953 to 300,000 in 1971. The larger the farm the more difficult it is to note escapes, and if escaped animals are to be recaptured it has to be done quickly while they are still hanging round 'home'. Where there is a mink farm there are almost certain to be escapes, despite the stringent requirements for a licence - a rat can gnaw a hole big enough to let a mink out. Westray should think again about welcoming mink if it values its unique field vole Microtus arvalis westrae and its ground-nesting birds, including corncrakes which are more numerous there than anywhere else in Orkney, waterfowl and major seabird breeding colonies in the North Atlantic.

The environment is beginning to hit back at us all now to such an extent that even ivory-towered bureaucratic machines in city centres have to take notice. The Commission of the European Communities has accordingly wheeled into the arena a nearly unreadable document in Burenglish EEC and that nevertheless may have an important impact on all the our lives. Environment Programme 1977-1981* restates Environment the aims and principles of EEC environment policy, especially on pollution, which is the way the environment is hitting back at us most sharply, and considers the protection and management of natural resources, including flora and fauna. The first fruits of this is the draft directive on bird protection, but the attempt to persuade all members of the EEC to adhere to the Washington Convention on trade in endangered species seems hardly to have got off the ground. In view of the unseemly wrangling by the EEC Fisheries Ministers, the further hope for a policy to conserve marine resources seems to be pie in a distant sky. But perhaps we should be thankful that the EEC, after ignoring the environment for so many years, not only recognises that it exists, but that it contains animals and plants.

* Office for Official Publications, BP 1003, Luxembourg, 90p. 